\title{
Insulin Signaling in Adipocytes Differentiated from Mouse Stromal MC3T3-G2/PA6 Cells
}

\author{
Satoshi Morito, ${ }^{a}$ Kuniko Yaguchi,${ }^{a, c}$ Mikiko Imada, ${ }^{b}$ Chihiro Tachikawa, ${ }^{b}$ Masaaki Nomura, ${ }^{c}$ \\ Shuzo Moritani, ${ }^{d}$ Manabu Igarashi, ${ }^{b}$ Koichi Yokogawa,,${ }^{a, b}$ and Ken-ichi Miyamoto ${ }^{*}, a, b$ \\ ${ }^{a}$ Department of Clinical Pharmacy, Graduate School of Natural Science and Technology, Kanazawa University; \\ ${ }^{b}$ Department of Hospital Pharmacy, School of Medicine, Kanazawa University; Kanazawa 920-8641, Japan: ${ }^{c}$ The Faculty \\ of Pharmaceutical Sciences, Hokuriku University; Kanazawa 920-1181, Japan: and ${ }^{d}$ The Faculty of Nursing and Welfare \\ Sciences, Fukui Prefectural University; Fukui 910-1195, Japan. Received May 31, 2005; accepted July 17, 2005
}

The stromal MC3T3-G2/PA6 (PA6) cells from mouse clavaria did not require insulin for differentiation into mature adipose cells, although insulin is well known to play a key role in adipocyte differentiation. Large lipid droplets were observed in the cytoplasm of PA6 cells, and mRNA expression of the adipose specific proteins (aP2, $\operatorname{PPAR} \gamma, \mathrm{C} / \mathrm{EBP} \alpha$, FAS, GLUT4, leptin, and adiponectin) as differentiation markers appeared or increased clearly in the cells at $8 \mathrm{~d}$ after stimulation without insulin. In addition, the glycerol released from the cells (lipolysis) was increased in a concentration-dependent manner by isoproterenol. However, the isoproterenol-induced lipolysis in the cells was not influenced by treatment with insulin, although that was observed in extramedullary adipocytes, 3T3-L1 cells. On the other hand, the 2-deoxy-D-[1- $\left.{ }^{3} \mathrm{H}\right]$ glucose uptake in differentiated PA6 cells also increased by insulin, as shown in other adipose cells. In the cells, insulin induced the phosphorylation of extracellular signal-regulated kinases (Erks), Akt at Ser 473 and ribosomal p70 S6 protein kinase (p70 S6K) at Thr 389, and the insulin-induced 2-deoxy-D- $\left[1-{ }^{3} \mathrm{H}\right]$ glucose uptake was inhibited by pre-treatment with wortmannin, an inhibitor of phosphatidylinositol 3-kinase (PI3K), or ML-9, an Akt inhibitor. These results suggest that the insulin signal for adipogenesis (lipogenesis) and lipolysis in bone marrow stroma PA6 cells differs from extramedullary adipocytes, such as 3T3-L1 cells.

Key words MC3T3-G2/PA6 cell; adipocyte; lipolysis; glucose uptake; insulin signal

Bone marrow stroma contains progenitors of skeletal tissue components such as bone, cartilage, the hematopoietic supporting stroma and adipocytes. ${ }^{1,2)}$ Among cell types, the adipocytes are perhaps the most abundant stromal cell phenotype in adult human bone marrow. Generally, adipocytes play an important role in systemic lipid metabolism and also contribute to adiposity, insulin resistance and atherogenesis. ${ }^{3)}$ Gimble et al. have reviewed the function of bone marrow adipocytes and proposed four hypotheses: (1) a passive role, simply occupying excess space in the bone marrow cavity; (2) an active role in systemic lipid metabolism; (3) a localized energy reservoir in the bone marrow; (4) direct contribution to the promotion of hematopoiesis and an influence on osteogenesis. ${ }^{4}$ However, the function of adipocytes in bone marrow is still controversial.

The stromal cell line MC3T3-G2/PA6 (PA6) was established from mouse clavaria as preadipocytes having the capacity to convert to mature adipose cells. ${ }^{5}$ Greenberger reported that corticosteroids accumulated lipids in primary cultured mammalian bone marrow preadipocytes, but insulin did not. ${ }^{6,7)}$ In addition, the adipogenesis in PA6 cells is also markedly accelerated by the addition of dexamethasone, but insulin is not required for the process. ${ }^{5}$ )

Insulin is a major hormone controlling critical energy functions such as glucose and lipid metabolism. Its effects result from insulin binding to a membrane receptor (insulin receptor), which is expressed highly on insulin target tissues, such as the liver, muscles and adipocytes ${ }^{8}{ }^{8}$ The binding leads to its receptor autophosphorylation and then to tyrosine phosphorylation of substrate proteins, such as insulin receptor substrates (IRSs). These allow for the formation of macromolecular complexes close to the receptor. The two main transduction pathways are the phosphatidylinositol 3- kinase (PI3K) pathway and the mitogen-activated protein kinase (MAPK) pathway. ${ }^{8-10)}$ The MAPK pathway is considered to be involved in nuclear effects, proliferation and differentiation, while the PI3K pathway plays a major role in insulin functions, mainly via activation of the Akt cascade. ${ }^{8,10)}$ Activation of Akt stimulates glycogen synthesis, protein synthesis, cell survival, inhibition of lipolysis, and glucose uptake. ${ }^{11)}$ However, nothing is known about insulin signaling in bone marrow adipocytes, which are unresponsive to insulin in the adipogenesis process.

Therefore, we assessed insulin signaling and its functions, such as glucose uptake and the inhibition of lipolysis, in adipocytes differentiated from bone marrow preadipocyte PA6 cells.

\section{MATERIALS AND METHODS}

Materials Alpha modification of Eagle's minimum essential medium ( $\alpha$-MEM) and Dulbecco's modified Eagle's medium (DMEM) were from ICN Biomedicals, Inc. (Irvine, CA, U.S.A.). The anti-actin antibody, fetal bovine serum (FBS), insulin, bovine serum albumin, isoproterenol, wortmannin and rapamycin were from Sigma-Aldrich Corp. (St. Louis, MO, U.S.A.). Kanamycin, U0126 and SB202190 were from EMD Biosciences (Calbiochem; San Diego, CA, U.S.A.). Phospho-specific Akt (Ser 473), phospho-specific p38 mitogen activated protein (MAP) kinase, phospho-specific p70 S6 kinase (Thr 389), and PhosphoPlus p44/42 MAP kinase antibody kits were from Cell Signaling Technology, Inc. (Beverly, MA, U.S.A.). ISOGENE, oil red O, dexamethasone (Dex) and 1-methyl-3-isobutylxanthine (IBMX) were from Wako Pure Chemical Industries, Ltd. (Osaka, Japan). The Molony murine leukemia virus (M-MLV) re- 
verse transcriptase and dNTP were from Promega Corp. (Madison, WI, U.S.A.). Taq DNA polymerase was from Invitrogen Corp. (Carlsbad, CA, U.S.A.).

Cell Culture The mouse stromal cell line, MC3T3G2/PA6 (PA6), ${ }^{5)}$ was purchased from the Riken Bioresource Center, Tsukuba, Japan, and maintained in $\alpha$-MEM supplemented with $10 \%$ heat-inactivated FBS and $60 \mu \mathrm{g} / \mathrm{ml}$ kanamycin in an atmosphere of $5 \% \mathrm{CO}_{2}$ at $37^{\circ} \mathrm{C}$. Differentiation was induced by treating the confluent cells with $\alpha$ MEM containing $0.5 \mathrm{~mm}$ IBMX, $0.25 \mu \mathrm{M}$ Dex and 10\% FBS for $4 \mathrm{~d}$. The cells were further cultured in $\alpha$-MEM supplemented with $10 \%$ FBS every other day for the subsequent $4-6 \mathrm{~d}$.

The mouse preadipocyte cell line, 3T3-L1 (L1) (Health Science Research Resources Bank, Osaka, Japan) was cultured in DMEM supplemented with 10\% FBS, 2 mM glutamine, 100 units $/ \mathrm{ml}$ penicillin $\mathrm{G}$ and $100 \mathrm{units} / \mathrm{ml}$ streptomycin in an atmosphere of $5 \% \mathrm{CO}_{2}$ at $37^{\circ} \mathrm{C}$. The differentiation of 3T3-L1 cells into adipocytes was initiated by the addition of $0.25 \mu \mathrm{M}$ Dex, $0.5 \mathrm{~mm}$ IBMX and $5 \mu \mathrm{g} / \mathrm{ml}$ insulin to the culture medium of confluent cells for $3 \mathrm{~d}$, followed by the cultivation of cells without supplements until differentiation. The media were changed every $2 \mathrm{~d}$.

Brown adipocytes were obtained from the interscapular brown adipose tissue of 3-week-old male C57BL/6J mice (Nippon SLC Corp., Hamamatsu, Japan) as described previously. ${ }^{12,13)}$ The tissue was minced in an isolation solution $\left(123 \mathrm{~mm} \mathrm{NaCl}, 5 \mathrm{~mm} \mathrm{KCl}, 1.5 \mathrm{~mm} \mathrm{CaCl}_{2}, 5 \mathrm{~mm}\right.$ glucose, $1.5 \%$ bovine serum albumin, $100 \mathrm{~mm}$ Hepes, $\mathrm{pH}$ 7.4) containing $0.2 \%$ collagenase type II (Wako Pure Chemical), and then digested for $30 \mathrm{~min}$ at $37^{\circ} \mathrm{C}$. The digest was successively filtered through a $250-\mu \mathrm{m}$ and $25-\mu \mathrm{m}$ nylon filter to remove undigested material and mature cells. The brown adipocytes were pelleted by centrifugation $(10 \mathrm{~min}$, $2000 \mathrm{rpm}$ ), washed and resuspended in DMEM. The brown adipocytes were seeded into 24-well plates and cultured in DMEM supplemented with 10\% heat-inactivated FBS and $100 \mu \mathrm{g} / \mathrm{ml}$ kanamycin in an atmosphere of $5 \% \mathrm{CO}_{2}$ at $37^{\circ} \mathrm{C}$.

Oil Red $\mathrm{O}$ staining Oil red $\mathrm{O}$ dissolved in isopropanol was kept overnight at room temperature, filtered, mixed with distilled water, kept overnight in the cold, and finally filtered twice before use. ${ }^{14)}$ The final staining solution was $0.2 \%$ oil red $\mathrm{O}$ in $60 \%$ isopropanol (working solution). Cells were washed twice with phosphate buffered saline (PBS) and fixed with $10 \%$ neutral formalin (Wako Pure Chemical) for at least $1 \mathrm{~h}$ at room temperature. The cells were washed twice with water, then stained for $2 \mathrm{~h}$ with the oil red $\mathrm{O}$ working solution. The cells were washed, counterstained with Mayer's hematoxylin solution (Wako Pure Chemical), washed exhaustively with water, and the excess water was evaporated by placing the stained culture at room temperature. The stained cells were observed under a microscope.

Reverse Transcription-Polymerase Chain Reaction (RT-PCR) Total RNA was isolated from PA6 cells by using an RNA isolation solution, ISOGEN. Synthesis of cDNA from the isolated total RNA was carried out using MMLV reverse transcriptase. A reverse transcription (RT) mixture was amplified by PCR using Taq DNA polymerase in the presence of $0.2 \mu \mathrm{M}$ sense and antisense primers. Primers used for mouse aP2 were $5^{\prime}$-AAC ACC GAG ATT TCC TTC AA$3^{\prime}$ and $5^{\prime}$-TCA CGC CTT TCA TAA CAC AT- $3^{\prime 15)}$; C/EBP $\alpha$
Table 1. Specific Condition for the Amplification of Each Gene

\begin{tabular}{llcc}
\hline \hline Genes & Annealing (s) & Elongation (s) & No. of cycles \\
\hline aP2 & $60^{\circ} \mathrm{C}(30)$ & $72^{\circ} \mathrm{C}(30)$ & 29 \\
PPAR $\gamma$ & $59^{\circ} \mathrm{C}(60)$ & $72^{\circ} \mathrm{C}(60)$ & 25 \\
C/EBP $\alpha$ & $67^{\circ} \mathrm{C}(60)$ & $72^{\circ} \mathrm{C}(60)$ & 30 \\
FAS & $62^{\circ} \mathrm{C}(60)$ & $72^{\circ} \mathrm{C}(60)$ & 30 \\
IR & $56^{\circ} \mathrm{C}(60)$ & $72^{\circ} \mathrm{C}(60)$ & 25 \\
IRS-1 & $64^{\circ} \mathrm{C}(60)$ & $72^{\circ} \mathrm{C}(60)$ & 30 \\
GLUT4 & $63^{\circ} \mathrm{C}(60)$ & $72^{\circ} \mathrm{C}(60)$ & 35 \\
Adiponectin & $58^{\circ} \mathrm{C}(30)$ & $72^{\circ} \mathrm{C}(60)$ & 32 \\
Leptin & $58^{\circ} \mathrm{C}(60)$ & $72^{\circ} \mathrm{C}(60)$ & 25 \\
$\beta$-Actin & $58^{\circ} \mathrm{C}(60)$ & $72^{\circ} \mathrm{C}(60)$ & 18 \\
\hline
\end{tabular}

5'-AGA CAT CAG CGC CTA CAT CG-3' and 5'-TGT AGG TGC ATG GTG GTC TG-3'16); peroxisome proliferatoractivated receptor- $\gamma$ (PPAR $\gamma$ (GeneBank NM_011146) 5' ATG GAA GAC CAC TCG CAT T-3' (sense 1675-1694) and 5'-CAT GGA CAC CAT ACT TGA G-3' (antisense 1093-1075); fatty acid synthase (FAS) (GeneBank AF127033) 5'-CCA AAC TGC AGC AGC ATG AT-3' (sense 3883-3902) and 5'-GGC TCT TTT CGG AGA CAA TT-3' (antisense 4414-4395); insulin receptor (IR) (GeneBank accession No. NM_010568.1) 5'-GTA GCC TGA TCA TCA ACA TCC-3' (sense 1142-1163) and 5'CCT GCC CAT CAA ACT CTG TCA C-3' (antisense 1693-1672); IRS-1 (GeneBank accession No. L24563) 5' GTG GCT TCT ATT GAG GAA TA-3' (sense 1618-1637) and 5'-ACC TTG GCA ATG AGT AGT AA-3' (antisense 2293-2274); GLUT4 (GeneBank AF098634) 5'-GTC ATG CGG ATC TTA TAC TT-3' (sense 573-592) and 5'-TCA TCA AGA AAG CCA CTG TT-3' (antisense 1036-1017); Leptin 5'-TGG AGA CCC CTG TGT CGG TT-3' and 5'AGC ATT CAG GGC TAA CAT CCA ACT-3'17); Adiponectin 5'-CAG GAT GCT ACT GTT GCA AGC-3' and $5^{\prime}$-TGC AGT CAG TTG GTA TCA TGG-3'18); $\beta$-actin 5'-TTC TAC AAT GAG CTG CGT GTG GC-3' and 5' -CTC (A/G)TA GCT CTT CTC CAG GGA GGA-3' ${ }^{19)}$ Specific conditions of each gene for PCR reaction are described in Table 1.

Lipolysis The differentiated adipocytes were washed two times with pre-warmed PBS and further $0.5 \mathrm{ml}$ of Dulbecco's balanced salt solution containing $2 \%$ bovine serum albumin and $4.5 \mathrm{mg} / \mathrm{ml}$ glucose (lipolysis buffer) with or without the addition of wortmannin $(100 \mathrm{~nm})$ or U0126 $(10 \mu \mathrm{M})$ was added. After incubation for $30 \mathrm{~min}$, the buffer was changed to the lipolysis buffer with or without wortmannin or U0126 in the presence or absence of insulin $(1 \mu \mathrm{M})$ and/or isoproterenol (indicated concentrations), and subsequently incubated for $1 \mathrm{~h}$. The buffer was collected and glycerol content was determined by the triglyceride E-test Wako (Wako Pure Chemical). The glycerol content was normalized for total cellular protein.

Glucose Uptake Cells cultured in 24-well plates were incubated in $\alpha$-MEM or DMEM containing $0.1 \%$ FBS for $24 \mathrm{~h}$ at $37^{\circ} \mathrm{C}$. Next, media were changed to Krebs-Ringer's phosphate buffer $(123 \mathrm{~mm} \mathrm{NaCl}, 4.94 \mathrm{~mm} \mathrm{KCl}, 1.23 \mathrm{~mm}$ $\mathrm{MgSO}_{4} \cdot 7 \mathrm{H}_{2} \mathrm{O}, 0.84 \mathrm{~mm} \mathrm{CaCl}_{2} \cdot 2 \mathrm{H}_{2} \mathrm{O}, 4.99 \mathrm{~mm}$ glutamine, $20 \mathrm{~mm} \mathrm{NaH} \mathrm{PO}_{4} \cdot 2 \mathrm{H}_{2} \mathrm{O}, 15 \mathrm{~mm}$ Hepes, $\mathrm{pH} 7.4$ ) and the cells were incubated for $2 \mathrm{~h}$ at $37^{\circ} \mathrm{C}$. Before the cells were exposed to insulin, they were treated or not treated with inhibitors in Krebs-Ringer's phosphate buffer for $1 \mathrm{~h}$. After in- 
cubation with or without insulin $(1 \mu \mathrm{M})$ for the indicated periods, 2-deoxy-D-[1- $\left.{ }^{3} \mathrm{H}\right]$ glucose was added and cells were subsequently incubated for $5 \mathrm{~min}$. The cells were washed twice with ice-cold PBS and then solubilized with $0.1 \%$ sodium dodecyl sulfate in $1 \mathrm{~N} \mathrm{NaOH}$. The radioactivity incorporated into the cells was measured by liquid scintillation spectroscopy.

Immunoblotting The differentiated PA6 cells cultured in 24-well plates were incubated in $\alpha$-MEM containing $0.1 \%$ FBS for $24 \mathrm{~h}$ at $37^{\circ} \mathrm{C}$. Media were changed to $\alpha$-MEM containing $0.1 \% \mathrm{FBS}$, and cells were incubated for another $2-4 \mathrm{~h}$ at $37^{\circ} \mathrm{C}$. Before the cells were exposed to insulin, they were treated or not treated with the inhibitors for $1 \mathrm{~h}$. Then, insulin $(1 \mu \mathrm{M})$ was added and the cells were subsequently incubated for an additional $5 \mathrm{~min}$ at $37^{\circ} \mathrm{C}$. The cells were then lysed, and immunoblot analysis performed by using the antibodies against actin or the phospho-specific antibodies against Akt, p70 S6K, p38 MAP kinase and extracellular signal-regulated kinases (Erks).

Antibody-bound proteins were detected by luminescence (ECL Western Blotting Kit, Amersham Biosciences) and analyzed using the Las-1000 lumino-imaging analyzer (Fuji Film, Tokyo, Japan).

\section{RESULTS AND DISCUSSION}

The stromal MC3T3-G2/PA6 (PA6) cell line was established from mouse clavaria and was known to have the ca- pacity to convert to mature adipose cells and to accumulate triglycerides in the cytoplasm. ${ }^{5)}$ The conversion into mature adipose cells is markedly enhanced in the presence of Dex. ${ }^{5}$ ) Preadipocytes required insulin, glucocorticoids and phosphodiesterase inhibitors, as external inducers, for the trigger of full differentiation into mature adipocytes. ${ }^{20-22)}$ Of those, insulin is well known to play a key role in adipocyte differentiation in vivo and in vitro. ${ }^{23-26)}$ However, PA6 cells do not always need insulin to convert to adipose cells, ${ }^{5,27)}$ as is the case with bone marrow preadipocytes. ${ }^{6,7)}$ Ding et al. have reported that TG accumulation when Dex and IBMX are given together was much more than that with Dex alone in PA6 cells. $^{27)}$ Our preliminary study also showed that insulin did not induce the adipocyte differentiation of PA6 cells in the presence or absence of Dex and IBMX. Therefore, we used Dex and IBMX (without insulin) for the differentiation of PA6 cells. PA6 cells exhibited a fibroblast-like morphology before stimulation with Dex and IBMX, but large lipid droplets were observed in the cytoplasm at $8 \mathrm{~d}$ after the stimulation (Fig. 1A). In addition, mRNA expression of the adipose specific proteins (aP2, PPAR $\gamma, \mathrm{C} / \mathrm{EBP} \alpha$, FAS, GLUT4, leptin, and adiponectin) as differentiation markers appeared or increased clearly in the cells (Fig. 1B). Isoproterenol induced glycerol release (lipolysis) from PA6 cells in a concentration-dependent manner (Fig. 1C). These results confirmed that PA6 cells differentiated into mature adipose cells in the absence of insulin.

On the other hand, although PA6 cells are unresponsive to

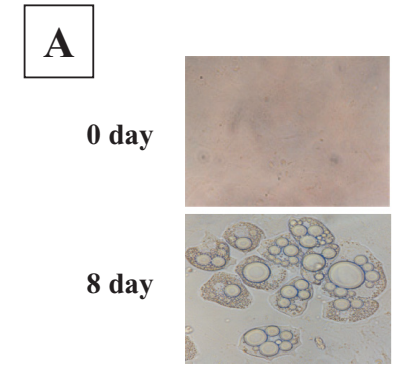

Microscopic image (x 400)

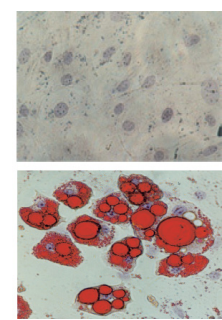

Oil red $O$ stain

(x 400)

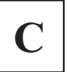

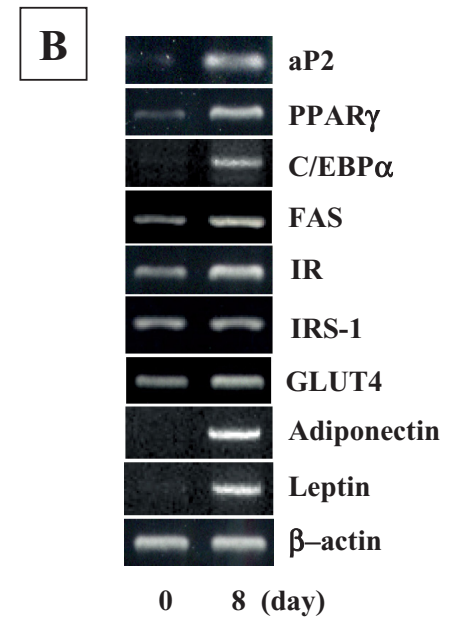

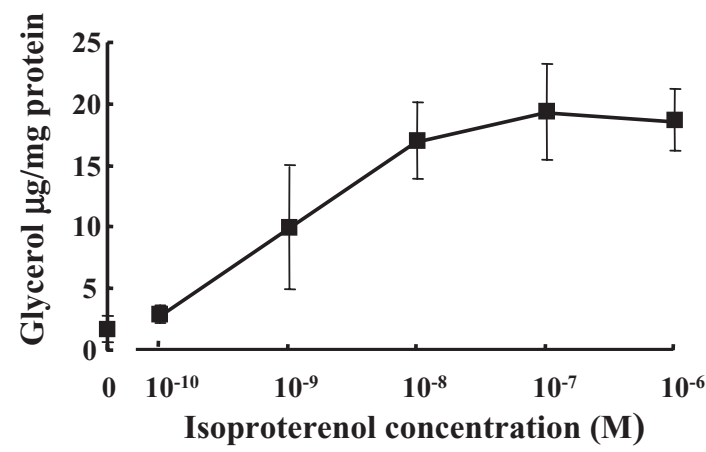

Fig. 1. Differentiation of Stromal PA6 Cells into Mature Adipose Cells

Differentiation of PA6 cells was induced culturing the confluent cells in $\alpha$-MEM containing $0.5 \mathrm{~mm}$ IBMX, $0.25 \mu \mathrm{M}$ Dex and $10 \%$ FBS for $4 \mathrm{~d}$. The cells were further cultured in $\alpha$-MEM supplemented with $10 \%$ FBS every other day for the following $4-6$ d. (A), The cells were stained with oil red O as described in Materials and Methods. (B), mRNA expression of aP2 (adipocyte fatty acid-binding protein 2), PPAR $\gamma$ (peroxisome proliferator-activated receptor gamma), C/EBP $\alpha$ (CCAAT/enhancer binding protein alpha), FAS (fatty acid synthase), IR (insulin receptor), IRS-1 (insulin receptor substrate-1), GLUT4 (glucose transporter 4), leptin, and adiponectin were measured by the RT-PCR method. (C), Glycerol release from the differentiated PA6 cells (lipolysis) by isoproterenol. Each value is the mean \pm S.E. of at least three experiments. 
insulin in the adipogenesis process, mRNA expression of IR and IRS-1 was observed all through the adipogenesis (Fig. 1B). Therefore, in this study, we assessed insulin signaling and its functions, glucose uptake and anti-lipolytic effect in differentiated PA6 cells.

As shown in Fig. 2A, insulin induced the phosphorylation of Erks, Akt at Ser 473 and ribosomal p70 S6 protein kinase (p70 S6K) at Thr 389, but not p38 MAP kinase, in the differentiated PA6 cells. It was confirmed that the insulin-induced phosphorylation of Erks was inhibited by U0126, a MEK inhibitor, and that wortmannin, a PI3K inhibitor, and ML-9, a known Akt inhibitor, ${ }^{28,29)}$ blocked the insulin-induced phosphorylation of Akt and p70 S6K, which is shown to be a downstream target of Akt. ${ }^{30-32)}$ On the other hand, the insulin-induced phosphorylation of $\mathrm{p} 70 \mathrm{~S} 6 \mathrm{~K}$ was attenuated by U0126 as well as inhibitors of the PI3K cascade, including rapamycin, an inhibitor of mammalian target of rapamycin (mTOR) (Fig. 2A). p70 S6K has been shown to be phosphorylated by MAP kinases, including Erks, ${ }^{33,34)}$ and our previ- ous reports also showed the blocking phosphorylation of $\mathrm{p} 70$ S6K by using the MEK inhibitors. ${ }^{35,36}$ Therefore, the phosphorylation of p70 S6K by insulin stimulation is probably regulated by Erks in differentiated PA6 cells.

Then, we measured insulin-induced uptake of 2-deoxy-D$\left[1-{ }^{3} \mathrm{H}\right]$ glucose in differentiated PA6 cells. The 2-deoxy-D-[1$\left.{ }^{3} \mathrm{H}\right]$ glucose uptake increased with the treatment time of insulin (Fig. 2B). The glucose uptake stimulated by insulin has been established to be through a PI3K-dependent pathway. ${ }^{37-40)}$ We examined whether the insulin-induced glucose uptake in the differentiated PA6 cells is blocked by inhibitors of the PI3K pathway. As shown in Fig. 3A, the insulin-induced 2-deoxy-D-[1-3 H]glucose uptake was inhibited by pretreatment with wortmannin or ML-9, but not rapamycin, U0126 or SB20190, a p38 MAP kinase inhibitor.

Because insulin-dependent glucose uptake in brown adipocytes is also known to be maintained mainly by a PI3Kdependent pathway, ${ }^{31)}$ we confirmed the effects of inhibitors of the insulin-signaling pathway on insulin-induced 2-deoxy-
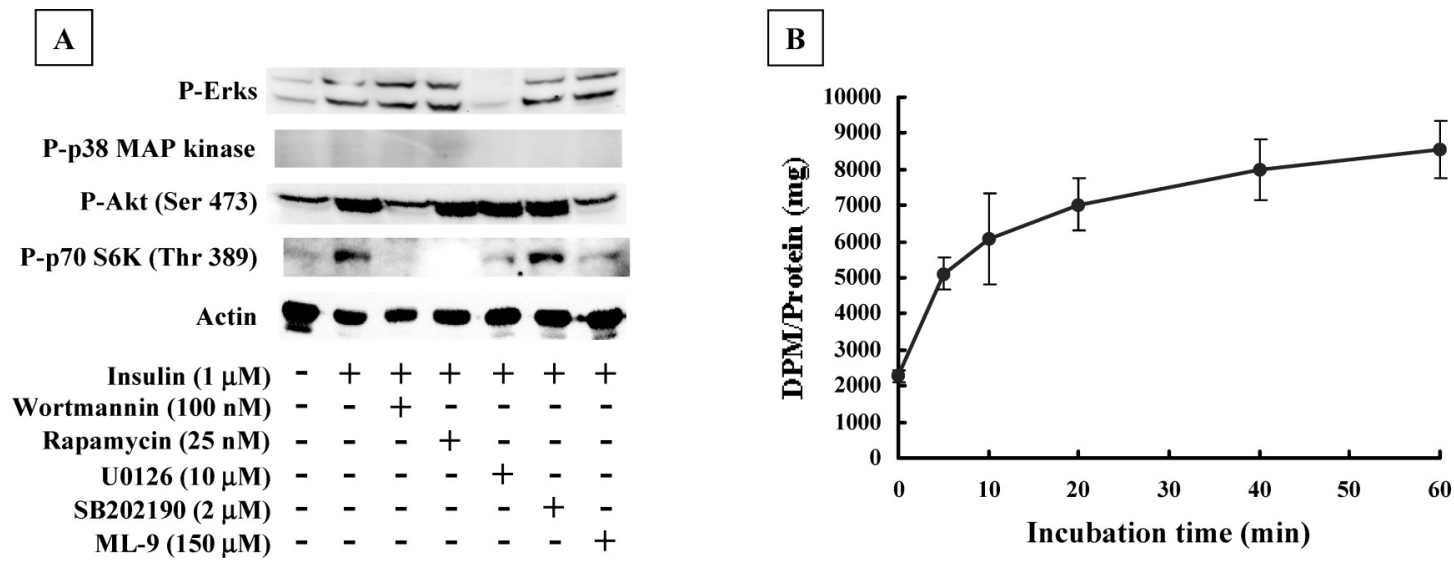

Fig. 2. Signaling and Glucose Uptake Induced by Insulin in the Differentiated PA6 Cells

(A), Differentiated PA6 cells were treated or not treated with kinase inhibitors for $1 \mathrm{~h}$. Then, the cells were incubated with or without insulin (1 $\mu \mathrm{M})$ for 5 min. The cells were lysed and the phosphorylation levels were estimated by immunoblotting with a phospho-specific antibody against p44/42 MAP kinase (Erks), p38 MAP kinase, Akt (Ser 473), or p70 S6K (Thr 389). Wortmannin, a PI3K inhibitor; rapamycin, an mTOR inhibitor; U0126, an MEK inhibitor; SB202190, p38 MAP kinase inhibitor; ML-9, an Akt inhibitor. (B), After treatment with insulin $(1 \mu \mathrm{M})$ for the indicated time, PA6 cells were incubated with 2-deoxy-D-[1- $\left.{ }^{3} \mathrm{H}\right]$-glucose for 5 min. Each value is the mean \pm S.E. of at least three experiments.
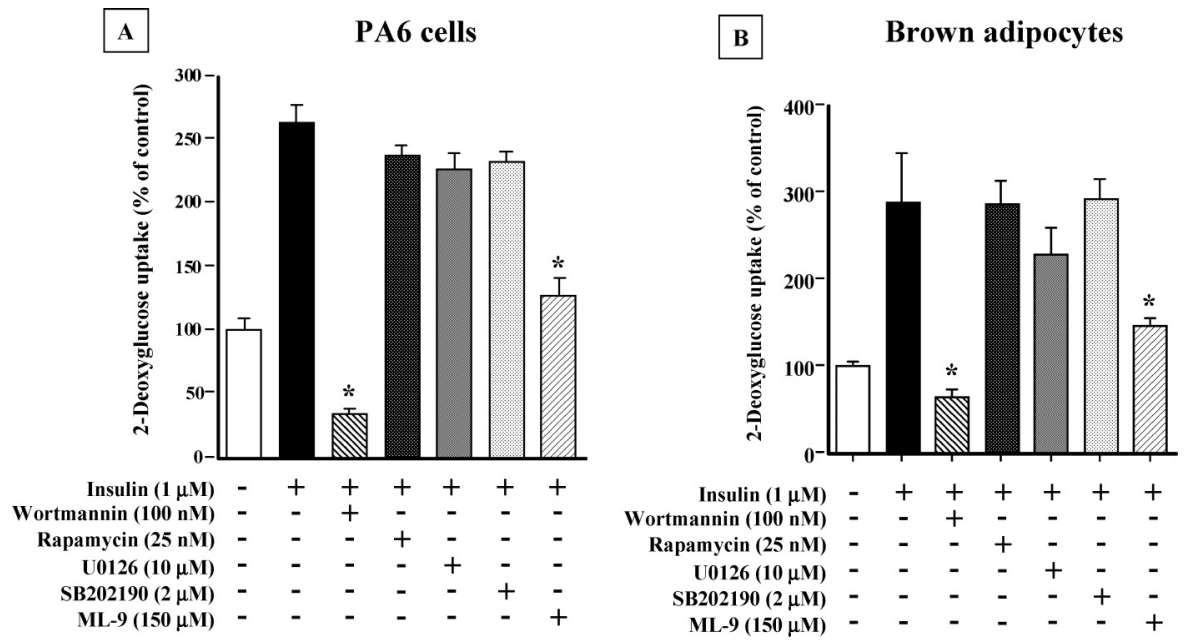

Fig. 3. Involvement of the PI3K Pathway in Glucose Uptake Induced by Insulin in Differentiated PA6 Cells (A) and Primary Cultured Brown Adipocytes (B)

The differentiated PA6 cells or primary cultured brown adipocytes were treated or not treated with kinase inhibitors for $1 \mathrm{~h}$. After incubation with or without insulin ( $1 \mu \mathrm{M})$ for $20 \mathrm{~min}, 2$-deoxy-D- $\left[1-{ }^{3} \mathrm{H}\right]$ glucose was added, and cells were subsequently incubated for $5 \mathrm{~min}$. Each value is the mean \pm S.E. of at least three experiments. $*$ Significantly different from insulin alone at $p<0.01$ 


\section{$\mathbf{A}$}

MC3T3-G2/PA6

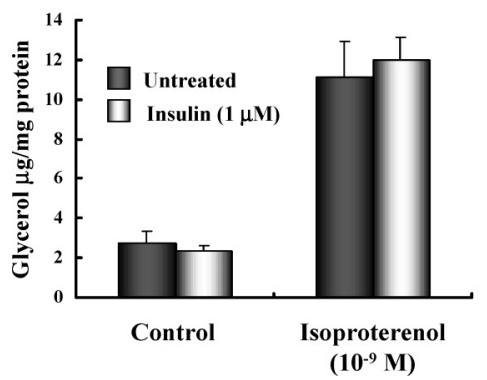

B

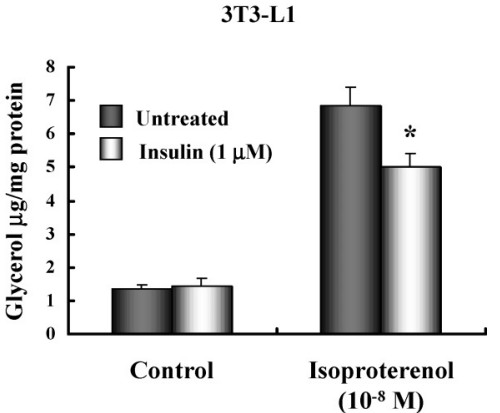

Fig. 4. Effect of Insulin on Isoproterenol-Induced Lipolysis

The differentiated PA6 cells (A) and L1 cells (B) were treated with the indicated concentration of isoproterenol in the absence or presence of insulin (1 $\mu \mathrm{M})$ for $1 \mathrm{~h}$. Glycerol content was normalized for total cellular protein. Data are presented as the mean \pm S.E. of at least three experiments. $*$ Significantly different from isoproterenol alone at $p<0.05$.

3T3-L1

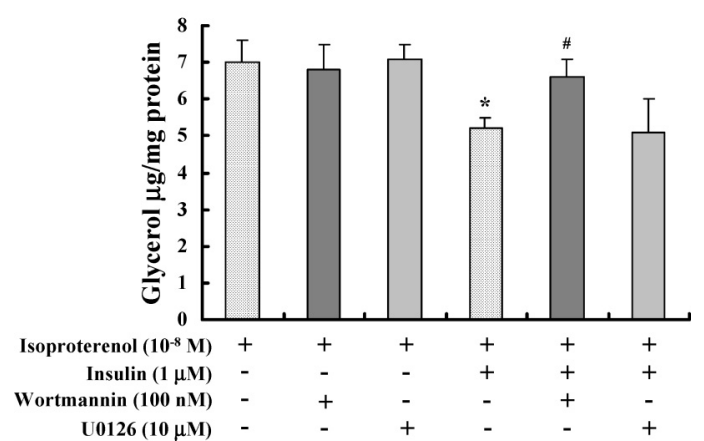

Fig. 5. The PI3K Pathway Is Involved In the Inhibition of IsoproterenolInduced Lipolysis by Insulin in Differentiated L1 Cells

The differentiated L1 cells were pre-treated with wortmannin (100 nM) or U0126 $(10 \mu \mathrm{M})$ for $30 \mathrm{~min}$. The cells were then treated with isoproterenol $\left(10^{-8} \mathrm{M}\right)$ in the absence or presence of insulin $(1 \mu \mathrm{M})$ for $1 \mathrm{~h}$. Glycerol content was normalized for total cellular protein. Data are presented as the mean \pm S.E. of at least three experiments. $*$ Significantly different from isoproterenol alone at $p<0.05$. \#Significantly different from isoproterenol + insulin at $p<0.05$.

D- $\left[1-{ }^{3} \mathrm{H}\right]$ glucose uptake in brown adipocytes. Wortmannin and ML-9 significantly inhibited 2-deoxy-D-[1- $\left.{ }^{3} \mathrm{H}\right]$ glucose uptake in the brown adipocytes, as in the case of PA6 cells (Fig. 3). The importance of the PI3K pathway on insulin-induced glucose uptake has also been reported in extramedullary adipocyte $3 \mathrm{~T} 3-\mathrm{L} 1$ (L1) cells. ${ }^{40,41)}$ Thus, insulin works in the glucose uptake of bone marrow adipocyte PA6 cells, as well as in brown adipocytes and L1 cells.

In adipose cells, insulin antagonizes lipolysis induced by catecholamines, ${ }^{42,43)}$ which activate adenylate cyclase and increase intracellular cAMP. This effect of insulin is suggested to result from the activation of phosphodiesterase 3B (PDE3B) through the PI3K/Akt pathway. ${ }^{42,44-46)}$ Consistent with these findings, insulin significantly inhibited isoproterenol-induced lipolysis in the differentiated L1 cells (Fig. 4B), and the inhibition by insulin was restored by pre-treatment with wortmannin, but not U0126 (Fig. 5). However, isoproterenol-induced lipolysis in the differentiated PA6 cells was hardly influenced by insulin (Fig. 4A). PDE3B mRNA expression was observed in both PA6 cells and 3T3-L1 cells after differentiation (data not shown). Therefore, PDE3B may be not regulated by insulin signaling in PA6 cells.

Very little is known about role of insulin in bone marrow. Moreover, the necessity and role of insulin in bone marrow adipocytes is still not clear. In this study, we demonstrated that insulin stimulated intracellular signaling, such as PI3K and MAPK pathways, and also affected glucose uptake in PA6 adipocytes, which have been suggested to be derived from bone marrow. ${ }^{5)}$ On the other hand, insulin did not inhibit isoproterenol-induced lipolysis in the cells. Although we did not examine isolated bone marrow adipocytes, the unresponsiveness to adipogenesis (lipogenesis)-antilipolysis of insulin might be characteristic of bone marrow adipocytes. These results provide novel insights into the property and function of bone marrow adipocytes.

\section{REFERENCES}

1) Gregoire F. M., Smas C. M., Sul H. S., Physiol. Rev., 78, 783-809 (1998).

2) Bianco P., Riminucci M., Gronthos S., Robey P. G., Stem Cells, 19 180-192 (2001).

3) Lyon C. J., Law R. E., Hsueh W. A., Endocrinology, 144, 2195-2200 (2003).

4) Gimble J. M., Robinson C. E., Wu X., Kelly K. A., Bone, 19, 421428 (1996).

5) Kodama H. A., Amagai Y., Koyama H., Kasai S., J. Cell Physiol., 112, $83-88$ (1982).

6) Greenberger J. S., Nature (London), 275, 752 - 754 (1978).

7) Greenberger J. S., In Vitro, 15, 823-828 (1979).

8) Saltiel A. R., Kahn C. R., Nature (London), 414, 799-806 (2001).

9) Virkamaki A., Ueki K., Kahn C. R., J. Clin. Invest., 103, 931-943 (1999).

10) Bevan P., J. Cell Sci., 114, 1429-1430 (2001).

11) Sen P., Mukherjee S., Ray D., Raha S., Mol. Cell. Biochem., 253, $241-246$ (2003)

12) Lindquist J. M., Fredriksson J. M., Rehnmark S., Cannon B., Nedergaard J., J. Biol. Chem., 275, 22670-22677 (2000).

13) Nechad M., Kuusela P., Carneheim C., Bjorntorp P., Nedergaard J., Cannon B., Exp. Cell Res., 149, 105-118 (1983).

14) Ramirez-Zacarias J. L., Castro-Munozledo F., Kuri-Harcuch W., Histochemistry, 97, 493-497 (1992).

15) Margareto J., Larrarte E., Marti A., Martinez, J. A., Biochem. Pharmacol., 61, 1471-1478 (2001).

16) Tamori Y., Masugi J., Nishino N., Kasuga M., Diabetes, 51, 2045-2055 (2002).

17) Parhami F., Tintut Y., Ballard A., Fogelman A. M., Demer L. L., Circ. Res., 88, 954-960 (2001).

18) Bensaid M., Gary-Bobo M., Esclangon A., Maffrand J. P., Le Fur G., Oury-Donat F., Soubrie P., Mol. Pharmacol., 63, 908-914 (2003).

19) Waki Y., Miyamoto K., Kasugai S., Ohya K., Jpn. J. Cancer Res., 86, 470-476 (1995).

20) MacDougald O. A., Lane M. D., Annu. Rev. Biochem., 64, 345-373 (1995). 
21) Cornelius P., MacDougald O. A., Lane M. D., Annu. Rev. Nutr., 14, 99-129 (1994).

22) Smith P. J., Wise L. S., Berkowitz R., Wan C., Rubin C. S., J. Biol. Chem., 263, 9402-9408 (1998).

23) Spiegelman B. M., Flier J. S., Cell, 87, 377-389 (1996).

24) Bluher M., Michael M. D., Peroni O. D., Ueki K., Carter N., Kahn B. B., Kahn C. R., Dev. Cell, 3, 25-38 (2002).

25) Bluher M., Patti M. E., Gesta S., Kahn B. B., Kahn C. R., J. Biol. Chem., 279, 31891-31901 (2004).

26) Bluher M., Wilson-Fritch L., Leszyk J., Laustsen P. G., Corvera S., Kahn C. R., J. Biol. Chem., 279, 31902-31909 (2004).

27) Ding J., Nagai K., Woo J. T., Biosci. Biotechnol. Biochem., 67, $314-321$ (2003).

28) Smith U., Carvalho E., Mosialou E., Beguinot F., Formisano P., Rondinone C., Biochem. Biophys. Res. Commun., 268, 315-320 (2000).

29) Hernandez R., Teruel T., Lorenzo M., FEBS Lett., 494, 225-231 (2001).

30) Nave B. T., Ouwens M., Withers D. J., Alessi D. R., Biochem. J., 344 427-431 (1999).

31) Sekulic A., Hudson C. C., Homme J. L., Yin P., Otterness D. M., Karnitz L. M., Abraham R. T., Cancer Res., 60, 3504-3513 (2000).

32) Nomura M., He Z., Koyama I., Ma W.-Y., Miyamoto K., Dong Z., Mol. Carcinog., 38, 25-32 (2000).

33) Mukhopadhyay N. K., Price D. J., Kyriakis J. M., Pelech S., Sanghera J., Avruch J., J. Biol. Chem., 267, 3325-3335 (1992).

34) Zhang Y., Dong Z., Nomura M., Zhong S., Chen N., Bode A. M., Dong Z., J. Biol. Chem., 276, 20913-20923 (2001).

35) Nomura M., Kaji A., He Z., Ma W.-Y., Miyamoto K., Yang C. S.,
Dong Z., J. Biol. Chem., 276, 46624-46631 (2001).

36) Nomura M., Kaji A., Ma W.-Y., Zhong S., Liu G., Bowden G. T., Miyamoto K.-I., Dong Z., J. Biol. Chem., 276, 25558-25567 (2001).

37) Lund S., Pryor P. R., Ostergaard S., Schmitz O., Pedersen O., Holman G. D., FEBS Lett., 425, $472-474$ (1998).

38) Tanti J. F., Gremeaux T., Grillo S., Calleja V., Klippel A., Williams L. T., Van Obberghen E., Le Marchand-Brustel Y., J. Biol. Chem., 271, $25227-25232$ (1996).

39) Kotani K., Carozzi A. J., Sakaue H., Hara K., Robinson L. J., Clark S. F., Yonezawa K., James D. E., Kasuga M., Biochem. Biophys. Res. Commun., 209, 343-348 (1995).

40) Sakaue H., Ogawa W., Takata M., Kuroda S., Kotani K., Matsumoto M., Sakaue M., Nishio S., Ueno H., Kasuga M., Mol. Endocrinol., 11, $1552-1562$ (1997).

41) Kohn A. D., Summers S. A., Birnbaum M. J., Roth R. A., J. Biol. Chem., 271, 31372-31378 (1996).

42) Eriksson H., Ridderstrale M., Degerman E., Ekholm D., Smith C. J., Manganiello V. C., Belfrage P., Tornqvist H., Biochim. Biophys. Acta, 1266, 101-107 (1995).

43) Elks M. L., Jackson M., Manganiello V. C., Vaughan M., Am. J. Physiol., 252, C342-C348 (1987).

44) Rahn T., Ridderstrale M., Tornqvist H., Manganiello V., Fredrikson G., Belfrage P., Degerman E., FEBS Lett., 350, 314-318 (1994).

45) Degerman E., Landström T. R., Wijkander J., Holst L. S., Ahmad F., Belfrage P., Manganiello V., Methods, 14, 43-53 (1998).

46) Ahmad F., Cong L. N., Stenson Holst L., Wang L. M., Rahn Landstrom T., Pierce J. H., Quon M. J., Degerman E., Manganiello V. C., J. Immunol., 164, 4678-4688 (2000). 